\title{
Summer Gardening in Urban Settings in Canada: Lessons Learned \& Sharing Experiences
}

\author{
S. A. Samarasinghe \\ 38, Leeds Avenue, Winnipeg, \\ Manitoba, Canada, R3T 3X2 \\ Corresponding Author: \\ Tele: 0012048888253 \\ Email:senaka24@yahoo.com
}

\begin{abstract}
In light of the fact that urban areas are, in general, responsible for about 75 percent of global energy consumption and 80 percent of global emissions, and as cities continue to grow that they will have a crucial impact on global climate change mitigation efforts, this article shares the lessons learned and experience gained though Summer Gardening in an urban setting in Winnipeg in Manitoba, Canada in 2013 on a number of key aspects, including household food and water security, climate change, carbon footprint, ecosystem management and indigenous knowledge etc.
\end{abstract}

KEYWORDS: Climate change, Gardening, Urban setting, Winnipeg

\section{Introduction}

A garden is a piece of land adjoining a house, used for growing flowers, fruit, or vegetables (Oxford Dictionary, 2014). In urban centres growing more plants can help to mitigate the impact of global warming. Avoiding use of chemical fertilizers and pesticides can reap wider environmental benefits.

The description of the surrounding area of the garden under study is as follows: The garden is located in Fort Richmond (South Section of Winnipeg City). With the expansion of the University of Winnipeg in early 1970s, southern edge of the city also began to expand. Due to the availability of space in this neighbourhood, large extents of land for backyard and front yard were allocated for each household. During this period more houses were built around the edges of the city. As a result, the core of the city (downtown) became an unattractive area for housing. This type of forced development to the fringes (around Perimeter Highway) of Winnipeg, is generally referred to as urban sprawl (Fernandez, 2014).

The neighbourhoods were developed with zoning policies, which resulted in the allocation of commercial areas; vide road system with sidewalks, urban forest (e.g. Dalhousie Forest), and individual detached homes. Urban planners give more 
weightage to mobility of the citizens, and access to widely located service centres, adopting the auto-centric planning methodology. Australian researchers Newman and Kenworthy (2006) have described this phenomenon as automobile dependency.

The four seasons are determined by the changing (approximately three months) of sunlight. But the heat of the sun is not considered. This is determined by how the planet orbits the sun and the tilt of its axis. The sun reaches its most northern point in the sky at local noon. After this date, the length of daylight starts to decrease (Table 1).

Table 1: Seasons with months and dates

\begin{tabular}{cccccc}
\hline Season & Months & Dates & $\begin{array}{c}\text { Shortest \& } \\
\text { Longest } \\
\text { Days }\end{array}$ & $\begin{array}{c}\text { Sunrise } \\
\mathbf{( 2 0 1 3 )}\end{array}$ & $\begin{array}{c}\text { Sunset } \\
\mathbf{( 2 0 1 3})\end{array}$ \\
\hline Winter & $\begin{array}{c}\text { Dec. Jan. Feb. } \\
\text { Mar. }\end{array}$ & $\begin{array}{c}\text { Dec. } 21-\text { Mar. } \\
20\end{array}$ & $\begin{array}{c}\text { Dec. } 21- \\
\text { Shortest day } \\
\text { of the year }\end{array}$ & $8.24 \mathrm{am}$ & $4.29 \mathrm{pm}$ \\
\hline Spring & Mar. Apr. May. & Mar. $21-$ Jun. \\
Jun. & 20 & & & \\
\hline Summer & Jun. Jul. Aug. Sep. & $\begin{array}{c}\text { Jun. } 21-\text { Sep. } \\
20\end{array}$ & $\begin{array}{c}\text { Jun. } 21- \\
\text { Longest day } \\
\text { of the year }\end{array}$ & $5.20 \mathrm{am}$ & $9.41 \mathrm{pm}$ \\
\hline
\end{tabular}

Fall Sep. Oct. Nov. Sep. 21 - Dec.

(Autumn) Dec. 20

Source: Geography and Climate of Winnipeg, Wikipedia

Winnipeg has a cold continental climate with a short, very warm summer and a long, cold winter. Despite the cold weather, the sky of Winnipeg is the clearest in Canada and Winnipeg enjoys much sunny weather all year round.

Most rainfall in Winnipeg occurs in summer. In summer the volume of moisture in the air tends to be the highest. The southern wind flows from the Gulf of Mexico spreading widely over the Canadian prairies and the plains of the U.S. and it is long enough to collect moisture. This storm track tends to generate thunderstorms.

Based on the average rainfall figures from 1981-2010, the normal summer rainfall is calculated to be $247.5 \mathrm{~mm}$. The total summer rainfall in 2011 was $93 \mathrm{~mm}$, considered to be the driest summer recorded in Winnipeg since rainfall records began in 1873. This rainfall data disclosed that the summer rainfall pattern in Winnipeg is not regular. It is interesting to note that during the summer seasons average maximum and minimum temperatures were higher and average sunshine hours par day were also higher than the winter season and average wind speed was also low (Table 2). This climate condition helps the plants to grow fast and produce quick output in a short period. 
According to Geography and Climate of Winnipeg, Winnipeg was the coldest city in the world with a population of over 600,000 (730,018 - Census of Canada, 2011) based on the average night time temperature from December to February, inclusive. However, Ulan Bator the capital of Mongolia is now the coldest city in the world with a population of 1.2 million by January 2013 .

Table 2: Climate and weather of Winnipeg

\begin{tabular}{|c|c|c|c|c|c|c|c|}
\hline Month & $\begin{array}{c}\text { Av. } \\
\text { Daily } \\
\text { Max. } \\
\text { Temp. } \\
\text { (C) }\end{array}$ & $\begin{array}{l}\text { Av. } \\
\text { Daily } \\
\text { Min. } \\
\text { Temp. } \\
\text { (C) }\end{array}$ & $\begin{array}{c}\text { Av. } \\
\text { Hours } \\
\text { Sun (per } \\
\text { day) }\end{array}$ & $\begin{array}{c}\text { Av. } \\
\text { Days } \\
\text { with } \\
\text { Rains }\end{array}$ & $\begin{array}{c}\text { Av. } \\
\text { Days } \\
\text { with } \\
\text { Snowfall }\end{array}$ & $\begin{array}{c}\text { Av. } \\
\text { Depth } \\
\text { Snow on } \\
\text { Ground } \\
\text { (cm) }\end{array}$ & $\begin{array}{c}\text { Av. } \\
\text { Wind } \\
\text { Speed } \\
\text { (km per } \\
\text { hr) }\end{array}$ \\
\hline January & -13 & -23 & 3.9 & 1 & 12 & 18 & 17 \\
\hline February & -9 & -19 & 4.9 & 1 & 8 & 20 & 17 \\
\hline March & -1 & -11 & 5.8 & 3 & 7 & 13 & 18 \\
\hline April & 10 & -2 & 8.0 & 5 & 3 & 3 & 18 \\
\hline May & 19 & 5 & 9.2 & 11 & 1 & 0 & 18 \\
\hline June & 23 & 11 & 9.4 & 13 & 0 & 0 & 16 \\
\hline July & 26 & 13 & 10.2 & 11 & 0 & 0 & 15 \\
\hline August & 25 & 12 & 9.0 & 10 & 0 & 0 & 15 \\
\hline September & 19 & 6 & 6.0 & 11 & 0 & 0 & 17 \\
\hline October & 11 & 0 & 4.7 & 8 & 2 & 0 & 18 \\
\hline November & -1 & -10 & 3.1 & 2 & 9 & 5 & 17 \\
\hline December & -10 & -19 & 3.2 & 1 & 11 & 10 & 17 \\
\hline
\end{tabular}

Average Daily Maximum Temperature - Minimum - Sunshine - Rain Days - Snow Days-Snow Depth - Wind Speed

Source: The Climate and Weather of Winnipeg, Manitoba

It is interesting to note that on November 25, 1998, the City of Winnipeg committed itself to the Federation of Canadian Municipalities Partners for Climate Protection (The city of Winnipeg, 1998). Under this arrangement, different strategies were planned to reduce green house gases.

\section{Problem Statement}

Urban areas are home to over half of the world population, and they (Urban areas) are playing an increasing role in responding to climate change (Rosenzweig et al., 2011). Adaptation to climate change requires local knowledge. It needs awareness and capacity to act through households and community organizations. It is therefore important to identify and initiate climate change adaptation mechanism at the household and small community levels. 


\section{Objectives}

The main objectives of the study are: (1) to gain experience - planting (e.g. vegetable and flowers) and maintaining the garden (2) to save potable water - by using rain water barrels to water plants during dry weather condition (3) to introduce a chemical free zone (fertilize, weedicides \& pesticides) - by manually removing invasive species mainly Dandelion (4) to preserve natural habitat- by creating a natural habitat area, (5) to reduce carbon footprint (reduce heating and cooling costs) by planting trees and hedges to control sun and wind exposure in both summer and winter, and (6) for utilization of indigenous knowledge.

\section{Results and Discussion}

To gain experience gardening, work began in summer 2013 in the City of Winnipeg, Fort Richmond neighbourhood. Within the boundaries of Winnipeg City there are 236 neighbourhoods, which have been geographically defined as the smallest unit of division with an average population of 4,000 approximately. Physically, a neighbourhood is a residential area with an appropriate mix of housing types, convenience type commercial facilities, transportation choices and where appropriate, schools, recreation, library or park facilities. Many have natural boundaries such as roads, railroads, bridges and rivers.

\section{Gaining Experience}

As the garden space is limited, appropriate planning is necessary in selecting vegetable plants that can deliver worthwhile results such as a combination of vegetables that the family enjoy most, and types of vegetables that can be eaten on a regular basis. Plants that take a small amount of space to grow, and use less water for growth can be produced as home-grown produce ready for harvest through the summer season. Varieties of vegetables were chosen to acquire diverse experiences in cultivating vegetables, such as those with edible flowers, kernels and roots. Each vegetable variety has its own type of growth pattern, such as bush type and climbing type. Growing location also vary as the vegetables selected depend on different climatic conditions. For instance, beans and peas need a warm location with shelter. Therefore, such plants are planted close to the house. Peas have not that successful.

Good crops were gained on beans, and hence it was used both as curry and salad. Due to the heat of the hot sun, the walls of the house get warm, and this helped the plants (e.g. tomato) to get hot air. As the best harvest was gained from tomato, it was consumed in different manner ways, such as salad, curry and jam. Due to the snowfall (first snowfall occurred on Sept. 17, 2013) the remaining tomato crop had to be harvested and removed from he beds. The half ripe and tipped tomatoes were kept in the deep-freezer. Brussels sprouts require cool weather and these plants were placed in a cooler area of the garden whereas carrots grow under hot sun and on beds raised in the centre of the garden. Different harvesting periods (from 50 days to winter season) of the crops helped consumption not only in the summer season, 
but also in the early winter. It is important to note that throughout the season the crops harvested were shared among neighbours in the vicinity and friends in the city (Table 3).

Table 3: Choosing vegetable varieties

\begin{tabular}{|c|c|c|c|c|}
\hline No. & Varieties & Type/Name & Climate Condition & Harvest Period \\
\hline (a) & $\begin{array}{l}\text { Flower \& } \\
\text { Fruiting }\end{array}$ & & & \\
\hline 1 & Tomato & $\begin{array}{l}\text { Bush } \\
\text { Celebrity }\end{array}$ & Warm growing & 50-100 days after planting \\
\hline 2 & Cucumber & Burpless & $\begin{array}{l}\text { Hot weather } \\
\text { (Tropical Plant) }\end{array}$ & 62 days after planting \\
\hline 3 & Pumpkin & Space-eaters & Warm growing & $75-100$ frost-free days \\
\hline 4 & Sweet Pepper & $\begin{array}{l}\text { Hungarian } \\
\text { Wax }\end{array}$ & Clod temperate climate & 75-90 days after planting \\
\hline 5 & Sweet Pepper & Sun Bell & Clod temperate climate & $75-90$ days after planting \\
\hline 6 & Sweet Pepper & Better Belle & Clod temperate climate & 75-90 days after planting \\
\hline (b) & Brassicas & & & \\
\hline 7 & $\begin{array}{l}\text { Brussels } \\
\text { Sprouts }\end{array}$ & & Cool weather crop & $\begin{array}{l}\text { Cover the plant } \& \text { harvest } \\
\text { in winter }\end{array}$ \\
\hline (c) & $\begin{array}{l}\text { Pods \& } \\
\text { Kernels }\end{array}$ & & & \\
\hline 8 & Peas & $\begin{array}{l}\text { Climbing } \\
\text { Plant }\end{array}$ & Warm sheltered site & 55-70 days after planting \\
\hline 9 & Beans & $\begin{array}{l}\text { Climbing } \\
\text { Plant }\end{array}$ & Warm sheltered site & 75-90 days after planting \\
\hline (d) & $\begin{array}{l}\text { Roots, Stems \& } \\
\text { Bulbs }\end{array}$ & & & \\
\hline 10 & Carrots & & Need full sun & 75-90 days after planting \\
\hline
\end{tabular}

Source: Author (based on Summer Gardening 2013)

There were a few perennials (mainly flower plants) surviving from the last season. For current season few plants were selected such as Winnipeg Park Rose and Barbara Sherwood. In the centre of the lawn a rubber lawn edging (with a diameter of a 6-feet circle) was allocated for flowers (both perennials and annuals). The lawn edge helped to protect the growth of grass into the flowerbed. In the centre of the main window a new rose plant was placed. Around this, fast growing annuals and few perennials were planted.

A flower box fixed onto the main window had multi-coloured annuals planted to give a good view from the main window. On the north end of the lawn (closer to the 
house) there was a tree that was taller than the roof. Between this tree and the road there was a flower bush, which had to be pruned during summer to maintain the shape of the bush (Table 4).

Table 4: Choosing flower varieties

\begin{tabular}{lll}
\hline & \multicolumn{1}{c}{ Varieties } & Type \\
\hline (a) & $\begin{array}{l}\text { Perennials } \\
\text { (Lives for more than 2-years) }\end{array}$ & \\
\hline 1 & Prairie Dusk & Hybrid Beard - Tongue \\
\hline 2 & Dusseldorf Pride & Thrift \\
\hline 3 & Fire-witch Pinks & Centaurea \\
\hline 4 & Montana Blue & Alpine Aster \\
\hline 5 & Happy End & Speedwell \\
\hline 6 & Barbara Sherwood & Cold Hardness \\
\hline 7 & Winnipeg Park Rose & \\
\hline 8 & Helenium & \\
\hline (b) & $\begin{array}{l}\text { Annuals } \\
\text { (Survive one growing season) }\end{array}$ \\
\hline 1 & African Daisy & \\
\hline 2 & Black-eyed Susan & \\
\hline 3 & Chain Ester & \\
\hline 4 & Geranium & \\
\hline Source: & Author (based & \\
\hline
\end{tabular}

Source: Author (based on Summer Gardening 2013)

\section{Save Potable Water}

In Canada and the US people used over 300 litres per day per person, and these two countries are the highest per capita domestic water users in the world (Environment Canada, 2004). According to Podaima (2011), 300.9 litres had been used per day per person, while the population was 683,200. It is evident that Winnipeggers were using little more water than the average for North America. In this report, a 31-day maximum consumption rate had been given as 242.1 mega litres (100,000 litres) for the period of June $30^{\text {th }}$ to July $30^{\text {th }}$. This consumption rate covers residential (indoor and outside) water use. In order to conserve potable water, five rain barrels (a main barrel of 208 litres and four smaller barrels) were purchased in early summer to collect rainwater from the rooftop.

To prevent mosquito breeding, all the barrels were covered with lids. As there was no devise to collect rainwater by gravity (from barrel to barrel) when the rain starts, it was necessary to pour water manually from the main barrel to the other four barrels. It is essential to record that not a drop of pipe-borne water was used for the plants during the season. Backyard is enclosed with a timber fence. Strip vegetation (live fence) was maintained along this timber fence. The live fence acted as buffer 
against the blowing wind, and soil erosion was also controlled. Because of the strip vegetation, the volume of the discharge rate of water into the storm water system was reduced. Lastly, the strip vegetation helped to maintain the habitat of birds and the bunny population.

\section{Introduction of a Chemical Free Zone}

Manitoba will introduce a ban on the sale and use of synthetic lawn pesticides effective from 2015. Conservation and Water Stewardship Minister Gord Mackintosh said the ban will apply to home lawns, patios, driveways, sidewalks, as well as school grounds, playing fields and playgrounds used predominately by children, and in health-care institution and child-care centre grounds. He also said that the homeowners would also be granted a one-year grace period after the law is in place before facing any penalties. It would not apply to agricultural lands, gardens, golf courses, sod farms and in cases where high-risk noxious weeds and poisonous and invasive species must be dealt with.

In this connection a news conference held by the minister, who said that the Province would consult the City of Winnipeg, the lawn-care industry and other groups as it prepares legislation for the next session of the legislature. Further, it was announced that the cosmetic pesticide ban received the support of many organizations such as the Canadian Cancer Society and the Canadian Association of Physicians for the Environment (Winnipeg Free Press, 2014). Even before the introduction of such progressive legislation last summer we did not use chemicals to maintain the lawn and to cultivate vegetables and flowers.

\section{Preserve Natural Habitat}

In the southeast corner of our backyard, a nearly five square meter area was allocated to maintain the natural habitat. The timber fence formed the two edges (east and north boundaries) of the habitat area. The other two boundaries (of the habitat area) had the lawn and the vegetable plots. Grass clippings normally collected were placed in reusable containers and paper yard waste bags for disposal.

During the season, we never threw out clippings, but spread them on the habitat area to be exposed to the direct sunlight (for about one week), and allowed to decompose. After this process, clippings were used as: (a) water saving mulch on the vegetable plots - and for release of valuable nutrients, and to prevent run-off during rainy time, while encouraging natural soil aeration by earthworms, (b) to refill the compose bin, and (c) the balance spread widely on the ground to prevent growth of grass and undergrowth (scrub) in the habitat area.

The multi-level canopy of trees and shrubs in this open area attracted different sizes of birds and also allowed butterfly communities to expand their living horizon. This type of land area is helpful for birds and butterflies, which are shrinking in their numbers. 


\section{Reduce Carbon Footprint}

Federer (1970) describes the effects of trees in modifying the urban microclimate. In the southern border of our backyard, there were two large trees about $56 \mathrm{~cm}$ in circumference (from the ground level). These were removed a few years ago as this area was covered with such trees. Two other tress of similar size (on the southern block of the home garden) provided cool shade during the hot summer. Further, the perennial flowers of these trees contributed edible seeds and nectar for the use of different types of birds. They also constantly used the birdbath kept in the habitat area. Fortunately, this summer was not that hot, and as a result, air conditioner was not used to maintain the coolness in the house, thus saving energy in running the air conditioner. However, all the windows had to be kept open to get cool air to the house.

\section{Composting}

The soil life is destroyed by regular application of chemical fertilizer and pesticide. Although fertilizer provides basic plant nutrients, it does not help to replenish of organic material. Applications of compost increases water retention of soil and reduce waste disposal. Composting is the natural process of breaking down organic material (yard waste namely, grass clippings and leaves) to produce a nutrient-rich, soil-like material. The process works with the help of micro organisms such as bacteria and fungi combined with air and moisture Grass clippings collected from the above mentioned natural habitat area was collected in the compost bin. During the season composting process is started, with the result, the compost bin has to refill monthly with clippings from the habitat area.

\section{Lawn Care}

During the winter, a layer of dead grass and leaves accumulated on top of the lawn, and this can be observed in early spring. It is important to note that without using any mechanical equipment, a spring-tined rake is used to remove these discarded materials. After this process some black patches can be observed with bare spots on the ground. Black patches are removed by applying new soil, fertilize and seeds, and the bare spots are attended by replacing new grass layer (Tukey, 2007). Aeration is needed to allow air to circulate at the grass roots and break the compacted topsoil. Without using a mechanically operated erector, a fork is used for this purpose.

Dandelion is a hardy perennial weed. They survive for many years, developing thick crowns up to 6 to 10 inches across. As the main root is long (more than 6 inches), they can survive any bad weather condition in winter. This plant cannot be easily dugout by hand due to its long main root. Dandelion Digger is a specialized tool that removes dandelion and a wide variety of individual weeds and their roots, with little soil disturbance. Instead of this digger, a lightweight Italian Hoe was utilized. As a result, in mid-summer, the main root died owing to lack of nutrition 
supply. As the Hoe was not heavy, every three days it was continuously worked for 2-3 hours to uproot weeds in the vegetable, flower and lawn areas.

However, it is interesting to note that all parts of the plant (leaves, flowers and roots) of the dandelion are edible and have medicinal and cooking uses. This has to be kept this in mind, because as a practice, young dandelion green parts are used as other leafy vegetables (such as spinach). The time before they produce a yellow flower is the best period to eat it as a raw vegetable. For older greens parts (which are always larger in size), it is necessary to be blanched or steamed to remove the bitterness. As the garden is maintained as a chemical free zone, there is no worry in consuming leafy vegetables including Dandelion. Because we had not used chemicals to the lawn, two black-ant colonies appeared within an area of $2 \mathrm{X} 2$ feet. Due to this situation, there appeared two grey coloured patches on the lawn, but we allowed them to remain intact in their natural habitat.

\section{Consequences of using Lawn Mowers}

Using electric or push reel mowers is the best way to cut down on emissions and noise pollution. Most of the power-operated lawn mowers use gasoline and natural gas, as they create sound pollution, as explained by Winnipeg City Council (2010) under its Property and Neighbourhood Standards. Under this section poweroperated lawn mowers are included as excessive noise generating equipment. As a result, the use of gasoline and natural gas lawn mowers are restricted before 7.00 am and after $9.00 \mathrm{pm}$, from Monday to Friday and from 9.00am and after 9.00pm on Saturdays, Sundays and statutory holidays. Any sound above $85 \mathrm{~dB}$ (decibel) can cause hearing loss, and an average lawn mower's sound decibel rating is around 90 $\mathrm{dB}$. To prevent adverse effects of noise exposure, personal hearing protection units (such as ear muffs or plugs) is recommended.

\section{Grass Cutting}

Current standard is to keep grass growing up to 2 or 3.75 inches. Taller grasses allow-shading effect on the soil surface, which reduces germination of weed seeds, particularly crabgrass. This is an excellent way to reduce or destroy unwanted vegetation. It is necessary to keep in mind that grass cutting duration depends on the growth and level of the grass. The clippings were never sent out as garden waste, but are spread on the habitat area to be taken as mulching for the next season and to protect erosion in this area.

\section{Utilization of Indigenous Knowledge}

\section{In Sri Lanka}

(1) Daily (during morning) we offered alms to Buddha (Buddha Pooja) and this food is removed from the shrine room before noon and kept out on a stand for birds and squirrels to consume. In this garden other than birds and squirrels there were 
bunnies. For the benefit of the bunnies the stands are fixed at the ground level in the habitat area. The food consumed by the birds, squirrels and bunnies. Due to the growing number of consumers more food had to be kept for their consumption. It is a well-known fact that the squirrels and bunnies disturb vegetable plants. As there was enough food for them, they did not cause any harm for the vegetable plantation. Natural habitat area is similar to the Kurulu Palu (Bird's Sanctuary) area allotted in the rice fields in Sri Lanka. In this area, farmer fixed a mesh on the rice field for birds to sit on it and consume ripped rice seeds. Traditional rice farmers allocate such a block of land for birds to consume ripped rice seeds and to protect the balance area from the birds.

(2) In tropical countries (including Sri Lanka) households' use preserved fruits and vegetables through solar drying methodology. As there was a good harvest of chillies, a portion of it was kept for solar drying. It takes a minimum of 16 hours with full sunlight and temperature about 28-30.

\section{In Canada}

In St. James-Assiniboia (Western Section of Winnipeg City) in Muriel Street, a person who migrated from Ukraine at the age of 10 with his parents is still maintaining traditional methods. He has a permanent cloth line to dry cloths during summer, and did not use the dryer to save energy. As a practice he maintained the garden without applying chemicals for flowers, vegetables and the lawn. Rainwater utilization mainly for vegetable cultivation is another tradition that he has been practicing to save potable water. In his adjacent backyard close to his boundary there is an apple tree, which is not maintained by the owner. After obtaining permission of the adjoining neighbour, he has been providing gravity-fed irrigation facility to the apple tree. As the neighbour was not interested of the crop, he plucked apples and prepared apple relish and apple pie filling.

\section{Lessons Learnt (Conclusions and Recommendations)}

During the summer season the house and the garden have to be utilized not only for living and planting, but also to regulate climate change effects, such as less energy consumption. (e.g.: not to make use of cloth dryer/air-conditioner and less utilization of fuel-powered garden equipment) and reduce carbon footprint (e.g. recycle, save water, prepare eco friendly products, plant trees, grow native plants, ensure chemical free planting). Manual labour has to be used to maintain these functions (e.g. there is no use of chemicals but undertaking rainwater harvesting). As a normal practice, households always desire to take shortcuts to allocate time for other conventional activities in summer. Gardeners are concerned about their habitual pattern of maintaining the garden but they are unaware of the global effect of their individual behaviour. It is important to note when applying the indigenous knowledge (e.g. allow animals' habitat \& other plants) the most applicable methodology is the answer to most of the ill effects. 
Stakeholder participation is essential to plan and implement sustainable summer gardening strategy. For this task there are three types of stakeholders namely, public services, private sector and citizens. Householders outsource some functions to private sector companies such as lawn and garden maintenance, garden machinery manufactures and suppliers, fertilizer supplies and other related partner companies. With the help of these stakeholders enabling strategies have to be identified and based on that strategy, the implementation date and period has to be finalized.

\section{References}

Census of Canada (2011).

Environment Canada (2004). "Wise water use".

Federer, C. A. (1970). "Effect of trees in modifying urban micro - climate". Symposium on trees and forests in an urbanizing environment, Amherst Mass, Cooperative extension service, University of Massachusetts. $23-28$.

Fernandez, L. (2014). "Fast facts: the high cost of low taxes and urban sprawl".

"Geography and Climate of Winnipeg". Wikipedia.

Newman, P. and J. Kenworthy (2006). "Urban design to reduce automobile dependence". Opolis: An International Journal of Suburban and Metropolitan Studies, 2(1).

Oxford Dictionary (2014). Oxford University Press.

Podaima, S. (2011). "The city of Winnipeg water and waste department: 2010 water consumption summary report".

Rosenzweig, C., W. D. Solecki, S. A. Hammer and S. Mehrotra (2011). "Climate change and cities: first assessment report of the Urban Climate Change Research Network". Cambridge University Press

“The City of Winnipeg” (1998). Climate Change Action Plan.

"The Climate and Weather of Winnipeg, Manitoba" (Living in Canada).

Tukey, P. (2007). "The organic lawn care manual: a natural, low-maintenance system for a beautiful, safe lawn".

Winnipeg City Council (2010). "Property and neighbourhood standards".

Winnipeg Free Press (2014). "Synthetic lawn pesticides ban becomes effective in 2015". 